\title{
Effect of the type of aluminium coagulant on effectiveness at removing pollutants from groundwater in the process of coagulation
}

\author{
Izabela Krupińska \\ University of Zielona Góra Institute of Environmental Engineering, 15 Prof. Z. Szafrana St, 65-516 Zielona Góra, Poland
}

\begin{abstract}
Coexistence of organic substances and iron in groundwater causes that a particular part of iron occurs in a form of iron-organic compounds as colloids or dissolved complexes, whereas water has an increased colour intensity and turbidity. Successful treatment of such water generates technological problems and is practically impossible by means of traditional groundwater treatment processes. Application of the coagulation process is one of the ways recommended for intensifying the removal of iron that occurs in a form of stable iron-organic compounds. The subject of research was groundwater from Quaternary formations with high concentration of total iron amounting to $7.0 \mathrm{mgFe} / \mathrm{dm}^{3}$ increased colour up to $41.0 \mathrm{mgPt} / \mathrm{dm}^{3}$ and turbidity up to $30 \mathrm{NTU}$, and also an increased amount of organic substances (TOC from 4.00 to $7.20 \mathrm{mgC} / \mathrm{dm}^{3}$ ) and manganese up to $1.80 \mathrm{mgMn} / \mathrm{dm}^{3}$. The water samples examined differed in terms of the value of the ratio of the TOC concentration and the concentration of total iron (D) and its turbidity and intensity of colour indicated the presence of colloidal and dissolved combinations of iron with organic compounds. The article discusses the effect of the type and dose of aluminium coagulan $\left(\mathrm{D}_{\mathrm{c}}, \mathrm{mgAl} / \mathrm{dm}^{3}\right)$ and the alkalinity, as well as the alkalinity ratio value $\left(\mathrm{r}=\mathrm{OH}^{-} / \mathrm{Al}^{3+}\right)$ of the tested aluminium coagulants on the efficiency of removing pollutants from groundwater containing iron-organic complexes. In order to oxidize $\mathrm{Fe}(\mathrm{II})$ to $\mathrm{Fe}(\mathrm{III})$ the groundwater samples were aerated with compressed air for 15 minutes. The efficiencies of four aluminium coagulants were compared: that of aluminium sulphate (VI) and those of three poly-aluminium chlorides (PAX XL-60, PAX-18, PAX-16) differing in alkalinity $(70 \%, 41 \%$ and $8.2 \%)$ and the alkalinity ratio value $(r=2.10,1.23$ and 0.25$)$. Coagulant doses expressed in $\mathrm{mgAl} / \mathrm{dm}^{3}$ and changed within the range of 1 to $6 \mathrm{mgAl} / \mathrm{dm}^{3}$. Volume coagulation was performed in $1 \mathrm{dm}^{3}$ groundwater samples using 1 minute rapid mix $(250 \mathrm{rpm})$ and 25 minute slow mix $(30 \mathrm{rpm})$ followed by 1 hour sedimentation. In the interpretation of the research results for the evaluation of the level of organic pollution in the water samples and its influence on the process and effectiveness of coagulation the coefficient of co-existence of organic substances and total iron D was used, calculated as D $=\mathrm{TOC} / \mathrm{Fe}_{\text {tot }}(\mathrm{mgC} / \mathrm{mgFe})$. Efficiency of disposal of wastes in the process of coagulation and sedimentation of post-coagulation solids depended on a type and dose of coagulant, alkalinity and alkalinity ratio of coagulant, coefficient of coexistence of organic substances and total iron in raw water, as well as on the temperature of the treated water. Among the coagulants types under analysis the best effects of removing iron compounds, organic substances and compounds causing coloring and turbidity were found for the pre-hydrolyzed coagulant PAX XL-60 possessing the highest alkalinity and the highest value of the alkalinity ratio.
\end{abstract}

Keywords: groundwater; organic substances; volume coagulation; aluminium sulphate (VI); poly-aluminium chlorides.

\section{Introduction}

Groundwater very frequently provides the only source of water designed for household supplies and then, its quality issues are important. A technological system of groundwater treatment depends on its chemical-physical composition, and, to a great extent, on concentration of water organic pollutants. In case of water with an increased content of organic substances, iron compounds and increased turbidity and colour intensity, application of the conventional groundwater treatment system does not ensure the required treatment efficiency [1]. This is a result of the presence of coloured, colloidal organoferric complexes with various degrees of water solubility, the removal of which requires coagulation process [2-11]. It was proved that aluminium coagulants were more efficient in treatment of such water than iron salts, due to the fact that products of aluminium hydrolysis, unlike iron, do not make coloured complexes with organic substances [12-15]. The total efficiency of coagulation process depends on: destabilization of colloidal pollutants and neutralization of anion charges by cation products of coagulant hydrolysis, ion exchange, surface complexing, adsorption on hydroxide particles of metals of coagulants applied and coprecipitation [16-18]. The role of the mechanisms referred to above depends on $\mathrm{pH}$ reaction of the

Corresponding author: Izabela Krupińska. E-mail address: i.krupinska@iis.uz.zgora.pl

http://dx.doi.org/10.3846/enviro.2014.082

(C) 2014 The Authors. Published by VGTU Press. This is an open-access article distributed under the terms of the Creative Commons Attribution License, which permits unrestricted use, distribution, and reproduction in any medium, provided the original author and source are credited. 
treated water, a quantity and charge of the products of coagulant hydrolysis as well as the initial concentration and form of organic substances [19]. Within the range of $\mathrm{pH}=4-6$ neutralization of the negative charge of pollutants being removed prevails, including of organic anions, whereas adsorption of pollutants on hydroxides of metals of coagulants employed is less significant. According to Jekel [20], adsorption on $\mathrm{Al}(\mathrm{OH})_{3}$ is crucial within the range of $\mathrm{pH}>7$, whereas according to Dempsey et al. [21], [22] it is within $\mathrm{pH}>6,25$. It was found out that the importance of $\mathrm{pH}$ value is bigger in case of removing pollutants that determine colour and the level of organic pollution than in case of pollutants responsible for turbidity [1]. In case of non-prehydrolyzed coagulants, such as aluminium sulphate (VI), for obtaining the desired amount of positive hydrolysis products it is required to lower the value of $\mathrm{pH}$, usually below 6 , which, unfortunately, leads to water corrosivity intensification [23]. This undesirable effect can be eliminated by applying prehydrolyzed aluminium coagulants of a higher alkalinity, the so called poly-aluminium chlorides. The solutions of the above mentioned coagulants feature, apart from aluminium monomers, polymerized products if the aluminium pre-hydrolysis of a big positive charge varying from 3 to 12 as well as a polymer $\left[\mathrm{Al}_{13} \mathrm{O}_{4}(\mathrm{OH})_{24}\right]^{7+}$ called the " $\mathrm{Al}_{13}$ " polymer. According to Edzwald et al. [24] the polymer " $\mathrm{Al}_{13}$ " is the most efficient of aluminium polymers in destabilizing negative colloids. Poly-cation products of aluminum prehydrolysis, after being added to the treated water, get hydrolyzed to $\mathrm{Al}(\mathrm{OH})_{3}$ more slowly than the aluminium present in aluminium sulphate (VI), furthermore, they remain in the "original" form of a wider $\mathrm{pH}$ range than in the situation when applying aluminium sulphate (VI) is applied [23-25]. This creates conditions for charge neutralization of organic anions by products of pre-hydrolysis before formation of $\mathrm{Al}(\mathrm{OH})_{3}$, playing mainly a role of an adsorbent of pollutants being removed. The pre-hydrolyzed coagulants cause smaller consumption of the natural water alkalinity and lower its $\mathrm{pH}$ reaction to a smaller extent than coagulants that are not pre-hydrolyzed. The alkalinity of poly-aluminium chloride is determined by the quotient of the number of moles $\mathrm{OH}^{-}$to $\mathrm{Al}^{3+}$ in a coagulant, referred to as the alkalinity ratio (r), which is approached as a coagulant polymerization degree measure. $\mathrm{Al}^{13+}$ polymer is the most stable and efficient in colloid destabilization of all aluminium polymers and its amount increases along with the alkalinity ratio (r) increase to 2 [1]. The polymeric structure of the hydrolysis products causes that poly-aluminium chlorides show agglomerating properties, thus improving flocculation conditions. The above mentioned properties of aluminium chlorides should ensure their greater usability for treatment of groundwater containing iron and organic substances as compared to non-prehydrolyzed aluminum coagulants. The article discusses the effect of the type and dose of aluminium coagulant and the alkalinity, as well as the alkalinity ratio value of the tested aluminium coagulants on the efficiency of removing pollutants from groundwater with an increased content of organic substances.

\section{Materials and methods}

The laboratory test material was groundwater from quaternary formations supplied to the water treatment plant "Zawada" near Zielona Góra (Poland). Conventional treatment of water (aeration, sedimentation and filtration) does not ensure sufficient removal of iron or colour and does not make water turbidity less. Value ranges of the selected coefficients of raw water physical and chemical composition are shown in table 1. The water subject to testing contained significant concentrations of iron, organic compounds and manganese, and its turbidity as well as colour intensity marked out the presence of colloidal and dissolved complexes of iron with organic compounds. For the purpose of oxidation of Fe (II) to Fe (III) the samples of raw water were subject to a 15 minutes' aeration with $90 \%$ of efficiency of oxidation of Fe(II) to Fe (III). Aeration, sedimentation and filtration with the speed of $5 \mathrm{~m} / \mathrm{h}$ through a sand bed covered with iron and manganese oxides did not guarantee that the treated water designed for human consumption could have the desired colour, turbidity and the concentrations of total iron and manganese, which were as follows: $25 \mathrm{mgPt} / \mathrm{dm}^{3}, 24 \mathrm{NTU}, 4 \mathrm{mg} \mathrm{Fe} / \mathrm{dm}^{3}$ and $0.80 \mathrm{mg}$ $\mathrm{Mn} / \mathrm{dm}^{3}$.

Therefore, it was decided to support water treatment with coagulation process. The objective of the tests was to determine the effects of alkalinity and the value of the alkalinity ratio of aluminum coagulants and doses of these coagulants on the efficiency of removing pollutants from groundwater after aeration in the volume coagulation process. It was assumed that poly-aluminium chlorides, due to the fact that their solutions contained aluminium polymers with a large positive charge, should be stronger than aluminium sulphate (VI) in removing pollutants from groundwater with an increased content of organic substances and total iron. In order to prove the assumptions accepted on a laboratory scale, several experiments on volume coagulation with poly-aluminium chlorides and aluminium sulphate (VI) treated as a control coagulant were carried out. Volume coagulation was performed in $1 \mathrm{dm}^{3}$ groundwater samples using 1 minute rapid mix $(250 \mathrm{rpm})$ and 25 minute slow mix (30 rpm). The following were used as coagulants: aluminium sulphate (VI) (SAL) as well as pre-hydrolyzed poly-aluminium chlorides with the trade names PAX-16, PAX-18 and PAX XL-60 that had different alkalinity ratio, alkalinity and aluminum content (table 2 ). The doses of coagulants were expressed in $\mathrm{mgAl} / \mathrm{dm}^{3}$ and varied from 1 to $6 \mathrm{mgAl} / \mathrm{dm}^{3}$. After coagulation the samples were subject to sedimentation process for 1 hour and filtration through a soft filter. Table 2 shows characteristics of the aluminium coagulants tested. 
Table 1. Groundwater quality indicators

\begin{tabular}{|c|c|c|c|c|}
\hline \multirow{2}{*}{ Indicator } & \multirow{2}{*}{ Unit } & \multicolumn{3}{|c|}{ Value } \\
\hline & & Minimum & Average & Maximum \\
\hline Temperature & ${ }^{\circ} \mathrm{C}$ & 8.0 & 12.5 & 13.0 \\
\hline $\mathrm{pH}$ & - & 7.00 & - & 7,28 \\
\hline Dissolved Oxygen & $\mathrm{mg} \mathrm{O}_{2} / \mathrm{dm}^{3}$ & 0.4 & 2.0 & 2.7 \\
\hline Colour & $\mathrm{mg} \mathrm{Pt} / \mathrm{dm}^{3}$ & 16 & 25 & 41 \\
\hline Turbidity & NTU & 3 & 17 & 30 \\
\hline Iron total & $\mathrm{mg} \mathrm{Fe} / \mathrm{dm}^{3}$ & 2.80 & 4.20 & 7.0 \\
\hline Iron (II) & $\mathrm{mg} \mathrm{Fe} / \mathrm{dm}^{3}$ & 1.20 & 1.50 & 2.0 \\
\hline Iron(III) & $\mathrm{mg} \mathrm{Fe} / \mathrm{dm}^{3}$ & 1.50 & 3.00 & 4.60 \\
\hline Manganese & $\mathrm{mg} \mathrm{Mn} / \mathrm{dm}^{3}$ & 0.40 & 0.80 & 1.80 \\
\hline Aluminum & $\mathrm{mg} \mathrm{Al} / \mathrm{dm}^{3}$ & 0.09 & 0.13 & 0.17 \\
\hline Alkalinity & $\mathrm{mval} / \mathrm{dm}^{3}$ & 3.00 & 3.50 & 4.10 \\
\hline TOC & $\mathrm{mg} \mathrm{C} / \mathrm{dm}^{3}$ & 4.00 & 4.73 & 7.20 \\
\hline $\mathrm{D}=[\mathrm{TOC}] /[$ Iron total $]$ & - & 0.62 & 1.18 & 1.75 \\
\hline
\end{tabular}

Table 2. Groundwater some properties of the aluminium coagulants tested [26-27]

\begin{tabular}{|c|c|c|c|c|}
\hline \multirow{2}{*}{ Indicator } & \multicolumn{4}{|c|}{ Type of coagulant } \\
\hline & PAX XL-60 & PAX-18 & PAX-16 & SAL \\
\hline $\begin{array}{l}\text { Alkalinity ratio, } \\
\mathrm{R}=\left(\mathrm{OH}^{-} / \mathrm{Al}^{3+}\right)\end{array}$ & 2.10 & 1.23 & 0.25 & - \\
\hline Alkalinity, \% & $70 \pm 10$ & $41 \pm 3$ & $8.2 \pm 0.2$ & 0 \\
\hline $\mathrm{Al}^{3+}, \%$ & $7.5 \pm 0.3$ & $9.0 \pm 0.3$ & $8.2 \pm 0.2$ & $4.2 \pm 0.2$ \\
\hline
\end{tabular}

When interpreting the test results in order to assess the organic pollution level of water samples and its effect on the process and efficiency of coagulation, the organic substance and total iron coexistence ratio D was applied which was calculated as: $\mathrm{D}=[\mathrm{TOC}] /\left[\mathrm{Fe}_{\text {tot }}\right](\mathrm{mgC} / \mathrm{mgFe})$. For the purpose of simplifying the records, the article does not list the $\mathrm{D}$ coefficient unit. The physical-chemical composition of both the raw as well as treated water was determined according to the International Standard methods. The temperature, $\mathrm{pH}$, dissolved oxygen of the raw water and the purified water was determined with an WTW Multi Line P4. The turbidity was determined by means of 2100P HACH turbidimeter. The colour (according to Pt scale), total iron, iron (II), iron (III), manganese, aluminum concentrations were determined with the Dr 3900 (HACH Lange) spectrophotometer. The alkalinity was determined with a titrimetric method against methyl orange. The organic carbon content was measured with a Shimadzu TOC apparatus. Prior to TOC measurement, the samples were acidified and bubbled with air, which did not contain any $\mathrm{CO}_{2}$, in order to remove the inorganic carbon. Raw and treated water samples were analyzed in the laboratory of drinking water University of Zielona Góra, Institute of Environmental Engineering (Poland).

\section{Results and discussion}

\subsection{The effect of the type and dose of a coagulant on the efficiency of removing pollutants}

Irrespectively of the physical-chemical composition of the treated groundwater the efficiency of removing pollutants (excluding manganese compounds) increased along with increasing the doses of the aluminium coagulants tested (Figs 1, 2).

The test results presented in Figures 1 and 2 also proved that the efficiency of the tested coagulants in removing iron compounds, the organic substance referred as TOC and in decreasing the water colour and turbidity increased along with an increase of the alkalinity and the alkalinity ratio $(r)$ of the aluminium coagulants tested, treated as a measure of the coagulant polymerization degree. The non-prehydrolyzed aluminium sulphate (VI) proved to be the least efficient aluminium coagulant. The efficiency of the tested coagulants in treating groundwater with similar values of the co-existence coefficient of organic substances and total iron (D) decreased according to the following row:

PAX XL-60 $(r=2.10)>$ PAX-18 $(r=1.23)>$ PAX-16 $(r=0.25)>$ SAL $(r=0)$ 
Irrespectively of the aluminum coagulant applied, an increase in its dose caused lowering of the tested water pH, which led to a decrease in the $\mathrm{Fe}$ (II) removal efficiency. The reverse effect of an increase of the coagulant dose and the concentration of $\mathrm{H}^{+}$ions was found in case of testing the efficiency of removing iron (III) and organic pollutants which is presented in Figures $3 \mathrm{a}$ and $3 \mathrm{~b}$ with samples of aluminium sulphate (VI) and coagulant PAX XL-60.

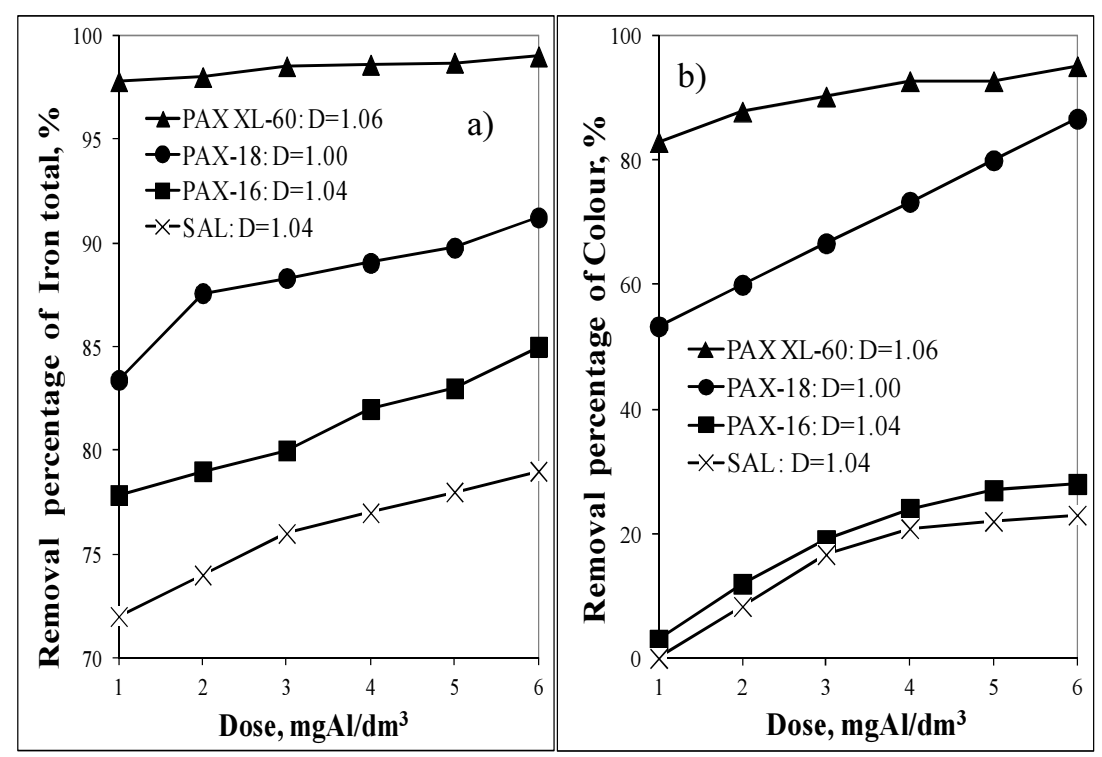

Fig. 1. The effect of the type and dose of a coagulant on the efficiency of removing total iron (a) and decreasing the colour (b)

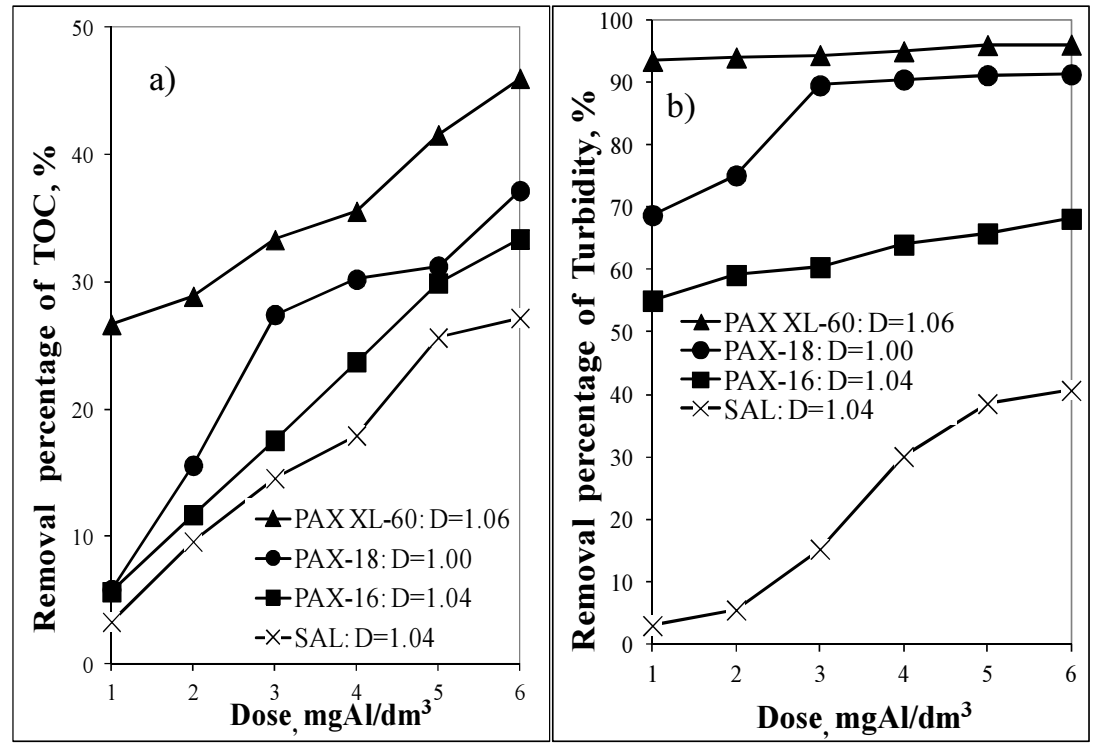

Fig. 2. The effect of the type and dose of a coagulant on the efficiency of removing TOC (a) and decreasing the turbidity (b)

Independently of the coagulant type used for the test, a degree of total iron, mainly Fe(III), concentration decrease correlated with the efficiency of removing organic substances (Table 3). This regularity was not found for $\mathrm{Fe}(\mathrm{II})$.

Table 3. Parameters of linear correlation between the amount of TOC removed and the amount of Fe(III) removed in the coagulation process

\begin{tabular}{lll}
\hline Type of coagulant & Linear correlation equation & Coefficient of the Pearson correlation (R) \\
\hline SAL & $\eta \mathrm{Fe}(\mathrm{III})=0.2851 \eta \mathrm{OWO}+89.497$ & 0.9896 \\
\hline PAX-16 & $\eta \mathrm{Fe}(\mathrm{III})=1.0853 \eta \mathrm{OWO}+56.159$ & 0.9886 \\
\hline PAX-18 & $\eta \mathrm{Fe}(\mathrm{III})=0.7124 \eta \mathrm{OWO}+74.654$ & 0.9696 \\
\hline PAX-XL60 & $\eta \mathrm{Fe}(\mathrm{III})=1.011 \eta \mathrm{OWO}+58.607$ & 0.9650 \\
\hline
\end{tabular}




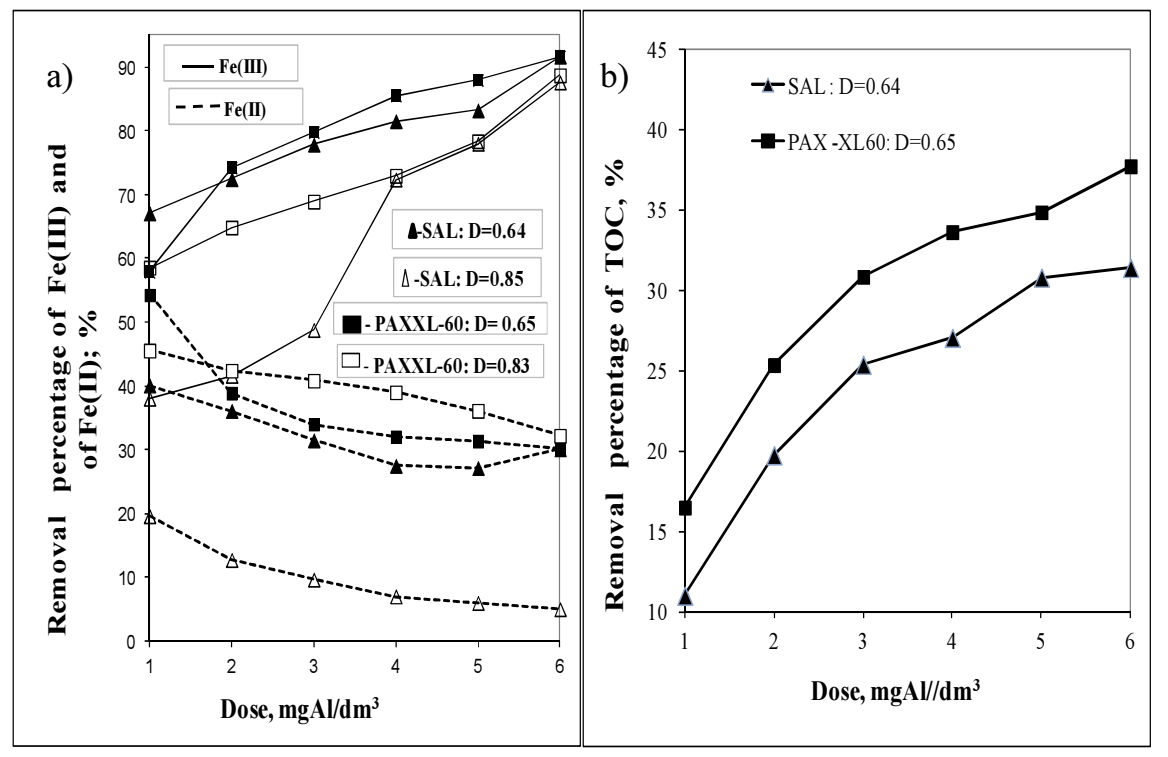

Fig. 3. The effect of the type and dose of a coagulant on the efficiency of removing Fe(III) and Fe (II) (a) and in lowering TOC (b)

The comparison of the doses of aluminium sulphate (VI) and poly-aluminium chlorides used for treating the same raw water ensuring a comparable, yet insufficient efficiency of removing total iron (60\%), TOC (22\%), turbidity (86\%) and colour $(87 \%)$ presented in table 4 , indisputably indicates the greatest efficiency of the pre-hydrolyzed coagulant PAX XL60 possessing the highest alkalinity and the highest value of the alkalinity ratio.

Table 4. The required doses of coagulants $\left(D_{\text {re }}\right)$ ensuring a comparable efficiency of removing total iron, organic substances and pollutants causing colouring and turbidity

\begin{tabular}{|c|c|c|c|c|}
\hline \multirow[t]{2}{*}{ Type of coagulant } & \multicolumn{4}{|c|}{$\mathrm{D}_{\mathrm{re}}, \mathrm{mgAl} / \mathrm{dm}^{3}$} \\
\hline & Iron total & Colour & Turbidity & TOC \\
\hline SAL & 5 & 5 & 5 & 4 \\
\hline PAX-16 & 4 & 4 & 3 & 3 \\
\hline PAX XL-60 & 2 & 2 & 2 & 2 \\
\hline
\end{tabular}

As a result of the coagulation process with all types of the tested coagulants, water alkalinity was used up and the concentration of hydrogen ions increased. Poly-aluminium chlorides caused much lower water acidification and lowering of alkalinity than aluminium sulphate (VI) for all the range of the doses of the tested coagulants $\left(\mathrm{D}_{\mathrm{c}}=1 \div 6 \mathrm{mgAl} / \mathrm{dm}^{3}\right)$, which is important in terms of water chemical stability. Differences in lowering water total alkalinity and water $\mathrm{pH}$ in relation to the type and dose of the coagulant used are shown in Figures $4 \mathrm{a}$ and $4 \mathrm{~b}$.

The dependencies presented in Figure 4 show that an increase in the alkalinity ratio of the pre-hydrolyzed coagulants decreased water acidification and consumption of its total alkalinity. The tests carried out also proved that both the coagulation as well as filtration through a soft filter were insufficient in removing manganese compounds, the concentration of which in the treated water increased with the coagulant dose. The highest concentration of manganese (1.7$1.0 \mathrm{mgMn} / \mathrm{dm}^{3}$ ) was found in water treated with aluminium sulphate (VI) which caused the highest water acidification. The tests also measured concentration of aluminium residual in water after coagulation, sedimentation and additional filtration. It was found that in this case poly-aluminium chlorides were more useful. The concentration of aluminium residual in water after coagulation exceeded the value of $0.2 \mathrm{mg} / \mathrm{Al} / \mathrm{dm}^{3}$, yet it was twice smaller in samples of water treated with polyaluminium chlorides than with aluminium sulphate (VI). A decrease in the concentration of aluminium ions to the allowable value of $\leq 0.2 \mathrm{mgAl} / \mathrm{dm}^{3}$ [28] was ensured by additional filtration of water samples treated with all the doses of polyaluminium chlorides tested. In case of aluminium sulphate (VI), a sufficient decrease of the concentration of the aluminium residual $\leq 0.2 \mathrm{mgAl} / \mathrm{dm}^{3}$ for drinking water [28] was guaranteed by filtration of water samples treated with coagulant doses of from 3 to $6 \mathrm{mgAl} / \mathrm{dm}^{3}$. A soft filter filtration caused further removal of after-coagulation suspensions and a decrease of the concentration of total iron, manganese and turbidity. The importance of the filtration process in terms of the total efficiency of water treatment was the smallest after applying a coagulant with the highest alkalinity ratio and alkalinity values that is PAX XL-60. On the other hand, the biggest contribution of filtration in total efficiency of water treatment was found after applying the least efficient coagulant, namely aluminium sulphate (VI) which is illustrated in Table 5. 


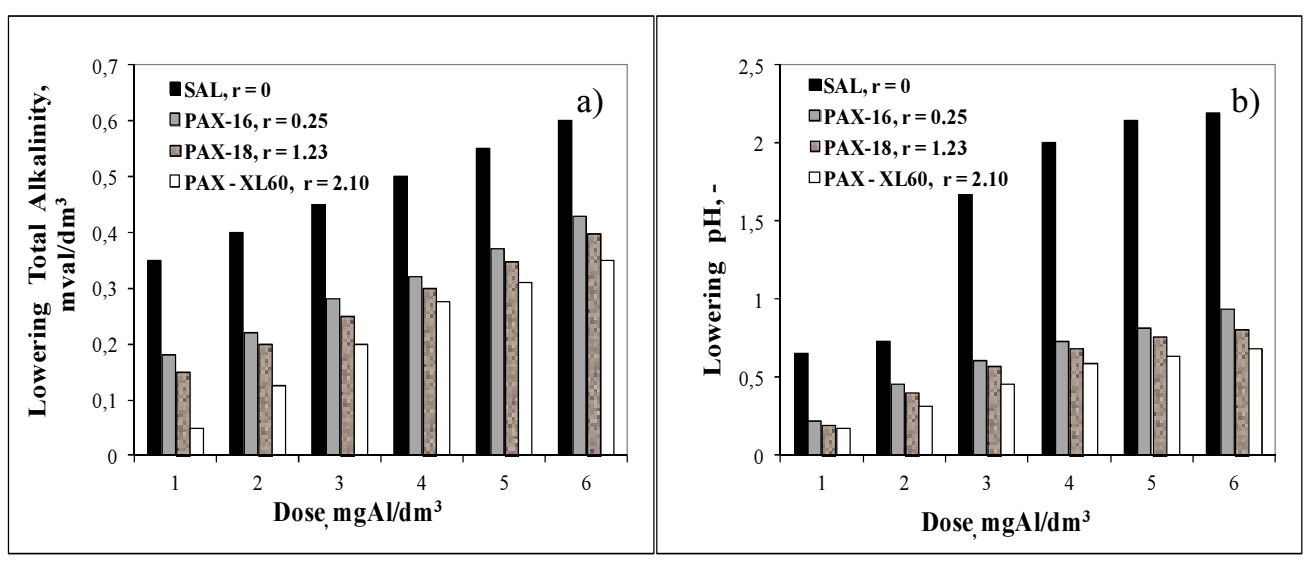

Fig.4. The effect of the type and dose of a coagulant on lowering total alkalinity (a) and $\mathrm{pH}$ (b) of the treated water

Table 5 . The effect of the type of the aluminium coagulant $\left(D_{c}=4 \mathrm{mgAl} / \mathrm{dm}^{3}\right)$ on the contribution of filtration in the total efficiency of removing total iron, turbidity, manganese and the residual aluminium

\begin{tabular}{lllll}
\hline Type of coagulant & $\begin{array}{l}\text { Efficiency of filtration, } \% \\
\text { Iron total }\end{array}$ & Manganese & Turbidity & Aluminum \\
\hline PAX XL-60 & 5 & 2 & 5 & 15 \\
\hline PAX-18 & 8 & 3 & 10 & 20 \\
\hline PAX-16 & 10 & 4 & 13 & 22 \\
\hline SAL & 15 & 10 & 20 & 35 \\
\hline
\end{tabular}

The results obtained also showed that the efficiency of the tested coagulants in removing pollutants from groundwater lowered along with an increase in the value of the coexistence coefficient of organic substances and total iron in raw water D (Table 6). The regularity found proves book references [21-22], [24] stating that an increase of the amount of organic ligands in raw water strengthens durability / life of organoferric combinations as well as the contribution of dissolved coloured, organoferric complexes, difficult to remove in the coagulation process.

Table 6 . The effect of the type of the coagulant $\left(\mathrm{D}_{\mathrm{c}}=1-6 \mathrm{mgAl} / \mathrm{dm}^{3}\right)$ and the value of the coefficient of coexistence of organic substances and total iron (D) in raw water on the efficiency $(\eta, \%)$ of removing pollutants from groundwater after aeration

\begin{tabular}{|c|c|c|c|c|c|c|}
\hline \multirow{2}{*}{ Type of coagulant } & \multirow{2}{*}{$\mathrm{D}=\mathrm{TOC} / \mathrm{Fe}_{\mathrm{tot}}$} & \multicolumn{5}{|c|}{ Efficiency of removing pollutants, $\%$} \\
\hline & & Iron total & Colour & Turbidity & TOC & Manganese \\
\hline \multirow{2}{*}{ SAL } & $\mathrm{D}=0.62$ & $79 \div 80$ & $46 \div 72$ & $10 \div 30$ & $60 \div 75$ & $15 \div 38$ \\
\hline & $\mathrm{D}=1.75$ & $50 \div 70$ & $15 \div 35$ & $7 \div 17$ & $20 \div 40$ & $14 \div 38$ \\
\hline \multirow{2}{*}{ PAX-16 } & $\mathrm{D}=0.62$ & $83 \div 88$ & $49 \div 74$ & $29 \div 40$ & $70 \div 85$ & $20 \div 40$ \\
\hline & $\mathrm{D}=1.75$ & $60 \div 70$ & $20 \div 40$ & $25 \div 30$ & $39 \div 48$ & $20 \div 40$ \\
\hline \multirow{2}{*}{ PAX-18 } & $\mathrm{D}=0.62$ & $85 \div 90$ & $50 \div 75$ & $55 \div 80$ & $66 \div 80$ & $38 \div 52$ \\
\hline & $\mathrm{D}=1.75$ & $74 \div 79$ & $25 \div 50$ & $48 \div 68$ & $40 \div 60$ & $40 \div 50$ \\
\hline \multirow{2}{*}{ PAXXL-60 } & $\mathrm{D}=0.62$ & $93 \div 98$ & $60 \div 78$ & $60 \div 90$ & $77 \div 92$ & $42 \div 58$ \\
\hline & $\mathrm{D}=1.75$ & $79 \div 84$ & $35 \div 60$ & $50 \div 80$ & $50 \div 70$ & $44 \div 59$ \\
\hline
\end{tabular}

The effect of the coefficient of coexistence of organic substances and total iron in raw water (D) on the difference in the efficiency of the tested aluminium coagulants while treating groundwater after aeration was the biggest when aluminium sulphate (VI) was applied (Table 6).

\subsection{The effect of temperature of the treated water on efficiency of the coagulation process}

Temperature is an important technological parameter in the coagulation process. According to various book references [1], [10], [23] it is presumed, that a decrease in the coagulation efficiency under low temperatures may be a result of lowering the speed of hydrolysis reaction and precipitation of cation hydroxides of the used coagulants as well as of the increased water viscosity. An increase of water viscosity lowers the sedimentation speed of after-coagulation fluffs formed and may also result in an increasing stability of removing colloids. In order to verify the contribution of temperature to the efficiency 
of the coagulation process with aluminium sulphate (VI) and poly-aluminium chlorides (PAX-16, PAX-18, PAX XL-60) a series of tests was performed for water with the same value of the coefficient of coexistence of organic substances and total iron $\mathrm{D}=1.22$ under two temperatures: $15^{\circ} \mathrm{C}$ and $25^{\circ} \mathrm{C}$. The test results presented in table 7 show that, independently of the type of a coagulant tested, a better efficiency of removing iron compounds, organic substances and of lowering the colour and turbidity was achieved when water was treated under the temperature of $25^{\circ} \mathrm{C}$.

Table 7. The effect of temperature $\left(15\right.$ and $\left.25^{\circ} \mathrm{C}\right)$ and type of a coagulant $\left(\mathrm{D}_{\mathrm{c}}=3 \mathrm{mgAl} / \mathrm{dm}^{3}\right)$ on efficiency of removing pollutants $(\eta, \%)$

\begin{tabular}{|c|c|c|c|c|c|c|c|c|}
\hline \multirow{4}{*}{ Type of coagulant } & \multicolumn{8}{|c|}{ Temperature of water; ${ }^{\circ} \mathrm{C}$} \\
\hline & 15 & 15 & 15 & 15 & 25 & 25 & 25 & 25 \\
\hline & \multicolumn{8}{|c|}{ Efficiency of removing pollutants, (\%) } \\
\hline & Iron total & Colour & Turbidity & TOC & Iron total & Colour & Turbidity & TOC \\
\hline PAX XL-60 & 90 & 80 & 90 & 20 & 97 & 90 & 97 & 25 \\
\hline PAX-18 & 78 & 60 & 75 & 16 & 90 & 88 & 90 & 21 \\
\hline PAX-16 & 60 & 50 & 60 & 12 & 75 & 80 & 85 & 17 \\
\hline SAL & 50 & 45 & 52 & 10 & 70 & 79 & 83 & 15 \\
\hline
\end{tabular}

As in case of earlier series of tests discussed, which determined the effect of a coagulant dose and type on the efficiency of removing pollutants from groundwater, the coagulant PAX XL-60 proved to be the most efficient in removing pollutants. The effect of temperature of the treated water on the varying efficiency of the coagulants used was the biggest in case of applying the non-prehydrolyzed aluminum sulphate (VI). It is confirmed by book references stating that pre-hydrolyzed coagulants are less susceptible to the negative effect of a low temperature of the treated water [1], [23]. The regularity found shows that in the period of low temperature of the treated water, that is under conditions of a smaller efficiency of aluminium hydrolysis, it is advisable to substitute the non-prehydrolyzed coagulant with poly-aluminium chlorides, especially hydrolyzed to a great extent, such as PAX XL-60.

\section{Conclusions}

The test results analysis leads to the following conclusions:

1. The efficiency of aluminium coagulants in removing pollutants from groundwater increased along with increasing their doses and alkalinity and the coagulant alkalinity ratio as well as along with an increase of the temperature of the treated water.

2. The effect of the coefficient of coexistence of organic substances and total iron in raw water (D) on varying efficiency of the tested coagulants in removing pollutants from groundwater was the biggest when the non-prehydrolyzed aluminum sulphate (VI) was used and its value lowered with an increase of alkalinity and the alkalinity ratio of the tested polyaluminium chlorides.

3. The best effects of removing iron compounds, organic substances and compounds cousing coloring and turbidity were found for the pre-hydrolyzed coagulant PAX XL-60 possessing the highest alkalinity and the highest value of the alkalinity ratio. The pre-hydrolyzed aluminium coagulant PAX XL-60 was the most efficient in removing pollutants from groundwater probably because of the highest amount of aluminium polymeric complexes with a large positive charge which effectively destabilize colloidal pollutants.

4. The poly-aluminium chlorides tested caused a smaller acidification of treated water as well as a lower consumption of water alkalinity than aluminium sulphate (VI), which is important in case of removing manganese as well as for the chemical stability of water.

5. Alkalinity of aluminium coagulants was decisive not only in terms of their efficiency in removing pollutants from groundwater, but also with respect to minimization of side-effects of the coagulation process, the so called aluminium residualt. The highest concentration of the aluminium residual was found in samples subject to coagulation with aluminium sulphate (VI).

6. Substituting aluminium sulphate (VI) with poly-aluminium chlorides (especially with highly alkaline ones) improved efficiency of removing pollutants from groundwater, as well as it decreased the required coagulant dose.

7. Owing to the efficiency of removing pollutants from groundwater, the required coagulant dose as well as undesirable effects of coagulation, the usability of the tested aluminium coagulants decreased as follows:

$$
\text { PAX XL-60 }(r=2.10)>\text { PAX-18 }(r=1.23)>\text { PAX-16 }(r=0.25)>\operatorname{SAL}(r=0),
$$

thus along with an increasing alkalinity and the value of the alkalinity ratio of the tested coagulants.

\section{References}

[1] Kowal, A. L.; Świderska-Bróż, M. 2009. Oczyszczanie wody, PWN, Warszawa-Wrocław. 802 p. ISBN 978-83-01-15871-2.

[2] Gonczarow, T. O.; Kołosow, I. W.; Kaplin, W. 1982. O formach nachorzdjenija metallow w poijerchnowstnych wodach, Gidrometeoizdat 77: 73-89.

[3] Knocke, R. W.; Conley, L.; Van Benschoten, J. E. 1992. Impact of dissolved organiccarbon on the removal of iron during water treatment, Water Research 26(11): 1515-1522. http://dx.doi.org/10.1016/0043-1354(92)90072-C

[4] Hrubec, J. 1995. The Handbook of Environmental Chemistry 5.B. Quality and Treatment of Drinking Water. Springer Verlag. 
[5] Arnold, C. G.; Ciani, A.; Muller, S. R.; Amirbahman, A.; Schwarzenbach R. P. 1998. Association of threeorganotin compounds with dissolved humic acid, Environmental Science Technologii 32: 2976-2983. http://dx.doi.org/10.1021/es980114z

[6] Pandey, A. K.; Pandey, S. D.; Mstra, V. 2000. Stability constants of metal-humic acid complexes and its role in environmental detoxification, Ecotoxicology and Environmental Safety 47: 195-200. http://dx.doi.org/10.1006/eesa.2000.1947

[7] Świderska-Bróż, M.; Krupińska, I. 2002. Skuteczność procesu koagulacji w usuwaniu związków żelaza z wód podziemnych, Ochrona Środowiska 3(86): 9-13.

[8] Lytle, D. A.; Magnuson, M.; Snoeyink, V. L. 2004. Effect of oxidants on the properties of Fe(III) particles andsuspensions formed from the oxidation of Fe(II), Journal AWWA 96(8): 112-124.

[9] Perchuć, M. 2004. Współudział żelaza i kwasów humusowych w kształtowaniu sposobu uzdatniania barwnych wód podziemnych, Oficyna Wyd. Politechniki Warszawskiej, Warszawa.

[10] Krupińska, I. 2006. Przydatność koagulacji w oczyszczaniu wody podziemnej ze szczególnym uwzględnieniem usuwania zwiazków żelaza, Rozprawa doktorska, Instytut Inżynierii Ochrony Środowiska Politechniki Wrocławskiej, Wrocław.

[11] Albrektiene, R.; Rimeika, M.; Lubyte E. 2011. The removal of iron-organic complexes from drinking water using coagulation process, Environmental Engineering The 8th International Conference, Vilnius, Lithuania, 2011. Vilnius: 509-512.

[12] Świderska-Bróż, M. 1992. Interakcja kwasów humusowych z kationami koagulantów oraz wybranymi metalami ciężkimi, Archiwum Ochrony Środowiska 1: 181-192.

[13] Kowalski, T. 1995. Wpływ właściwości chemicznych zanieczyszczeń wód na dobór koagulantów, Ochrona Środowiska 4(59): 3-8.

[14] Libecki, B.; Dziejowski J. 2008. Optamization of humic acids coagulation with aluminum and iron (III) salts, Polish Journal of Environmental Study 17( 3): 397-403

[15] Libecki, B.; Dziejowski, J. 2010. Changes in iron(II) and iron(III) content in solution of humic acids during coagulation by means of monomeric iron(III) salts, Polish Journal of Environmental Study 19(5): 1089-1093.

[16] Tipping, E.; Woof, C.; Backes, C.A.; Ohnstad M. 1988. Aluminum speciation in acidic natural waters: testing of a model for Al-humic complexation, Water Research 22(3): 321-326. http://dx.doi.org/10.1016/S0043-1354(88)90140-6

[17] Huang, C.; Shiu, H. 1996. Interactions between alum and organics in coagulation, Colloids and Surface 113: 155-163. http://dx.doi.org/10.1016/0927-7757(96)03543-1

[18] Lee, S. H; Kim, Ch. G; Yoon, T. 2003. Comment on the interaction of humic substances with cationic polyelectrolytes, Water Research 37: 715-716. http://dx.doi.org/10.1016/S0043-1354(02)00355-X

[19] Eikebrokk, B.; Fettig, J. 1990. Treatment of coloured surface water by coagulation. Direct filtration: effect of water quality, type of coagulant and filter aids, Chemical Water and Wastewater Treatment, Springer-Verlag: 361-376.

[20] Jekel, M. R. 1986. Interactions of humic acids and aluminum salts in the flocculation process, Water Research 12: 1535-1542. http://dx.doi.org/10.1016/0043-1354(86)90118-1

[21] Dempsey, B. A.; Ganho, R. M.; O Melia, C. R. 1984. The coagulation of humic substances by means of aluminum salts, JAWWA 76: 141-150.

[22] Dempsey, B. A.; Sheu, H.; Tanzeer Ahmed, T.M.; Mentink, J. 1985. Polyaluminum chloride and alum coagulation of clay-fulvic acid suspensions, JAWWA 3: 74-80.

[23] Rak, M. 2001. Wpływ alkaliczności koagulantów glinowych na ich skuteczność oraz agresywność kwasowęglową wody po koagulacji, Rozprawa doktorska, Instytut Inżynierii Ochrony Środowiska Politechniki Wroctawskiej, Wrocław.

[24] Edzwald, D. K.; Pernitsky, D. J.; Parmenter, W. L. 2000. Polyaluminum coagulants for drinking water treatment, chemistry and selection, Chemical Water and Wastewater Treatment VI, Springer-Verlag: 3-14.

[25] Kam, S. K.; Gregory, J. 2001. The interaction of humic substances with cationic polyelectrolytes, Water Research 35(15): 3557-3566 http://dx.doi.org/10.1016/S0043-1354(01)00092-6

[26] Zakłady Chemiczne Kemipol Ltd. 2000. PAX XL-60, PAX-18, PAX-16, Manufacturer's specification.

[27] Zakłady Chemiczne Ztotniki S.A. 1999. Aluminium sulphate (VI), Manufacturer's specification.

[28] Rozporzadzenie Ministra Zdrowia z dnia 29 marca 2007 w sprawie, jakości wody przeznaczonej do spożycia przez ludzi. Dz.U. nr 6, poz.417. 